\title{
1. Introduction to the complex relationships in international criminal justice
}

International criminal justice presents many challenges. Consider the following: Libya and the International Criminal Court (ICC) competed to try Saif al-Islam Gaddafi and his cohorts. However, neither Syria nor the ICC is attempting to try individuals for atrocity crimes. Why does such an imbalance exist in addressing international criminal issues? In the complex world of international criminal justice, multiple levels of actors and complicated priorities interface to pose obstacles to effective and efficient justice. International criminal courts, individual states, the United Nations (UN), regional organizations, inter-governmental organizations, and civil society are all part of the landscape of international justice. It is inevitable that, with so many actors, there are different priorities and motivations behind choices on international justice. Imbalances and inequities result in this complex setting. The different situations of Libya and Syria are the consequence of choices by international actors, such as the United Nations Security Council (referred to in this volume as Security Council), and national actors in state governments, as well as being a product of the nature of the conflicts.

The ICC must navigate this world of multiple constituencies and issues. Our goal in this book is to examine factors that shape the relationships among the various actors and international criminal courts. Although they differ in their legal frameworks, the UN international and hybrid courts that preceded the ICC share many similarities with the ICC in the challenges that they faced. We will explore and evaluate the experiences of the earlier courts on key issues and approaches that they developed. The assessment of those courts informs recommendations that we will make for the ICC as the Court seeks to forge effective partnerships with its States-Parties and the multiple constituencies it was intended to serve.

Throughout the book, four themes will pervade the discussion. First, accountability for atrocity crimes is often stated as a strongly desired 
goal of international and national jurisdictions. In our context, accountability means individual responsibility, whether through a criminal prosecution or through another type of proceeding. Although differences may exist in a given case on who bears responsibility and how best to achieve accountability, "justice" in some form is a common refrain. The precise meaning of justice has eluded legal philosophers for centuries. It has multiple and sometimes conflicting meanings, depending on the context. For our purposes, by justice we mean achieving one or more goals typically associated with a criminal process: retribution, deterrence, incapacitation, an expression of moral condemnation, or rehabilitation.

Second, there is a tension between international justice and politics. States comprising the parent bodies of international criminal courts, whether in the Security Council or in the Assembly of States Parties (ASP) of the ICC, have national and foreign policy interests. Moreover, when considering choices within a national jurisdiction, there will also be political motivations. It is a fact of life for international justice that political interests will affect some decisions and choices. At the same time, at both the international and national levels there is a need to strive for impartial, independent, and fair justice. The challenge we must confront is how to achieve it in light of these realities.

Third, there is a need for greater national capacity to prosecute serious international crimes. In order to be a full partner in international justice, states need to have the legal framework and the expertise to handle atrocity crimes. This includes not just passing the relevant legislation, which itself is often considered an achievement, but creating the institutional structures, providing the necessary resources, and adopting the relevant policies to give effect to the commitments expressed in legislation. But states are not the only contributors to national capacity. This is an evolving area in which there are many players, including the international criminal courts, regional courts, inter-governmental organizations, and non-governmental groups.

Fourth, the legitimacy of an international criminal court is crucial. Legitimacy, which is another multidimensional concept, can be defined in terms of actual and perceived legitimacy. ${ }^{1}$ Actual legitimacy is a normative value; for our purposes, it refers to the fairness of the proceedings.

1 See Margaret M. deGuzman, Gravity and the Legitimacy of the International Criminal Court, 32 FordHAM INT'L L. J. 1400, 1436-1438 (2008) (defining legitimacy as "justified authority" and describing three categories of legitimacy-legal, moral, and sociological-noting that there is overlap among the categories); Allison Marston Danner, Enhancing the Legitimacy and Accountability of Prosecutorial Discretion at the International Criminal Court, 97 AM. J. 
Perceived legitimacy is a sociological function; in our context, it refers to the perception of credibility of a court in the eyes of those most affected by the judgments and by the international community more broadly. No partnership with national or regional entities will succeed if the international level is viewed as illegitimate. An international criminal court cannot operate effectively without the cooperation of states. The acceptance and credibility of an international criminal court is an indispensable element in the relationship with national jurisdictions.

One or more of these themes will surface in each chapter as we consider the experience of international criminal courts that both predate and are contemporaneous with the ICC. We will also explore the ICC's experience with the issues to date. There are several courts that are important in providing a bank of experiences from which the ICC can learn and benefit, but for the purposes of this book, our focus is on the following:

International Criminal Tribunal for the former Yugoslavia (ICTY) International Criminal Tribunal for Rwanda (ICTR)

Special Court for Sierra Leone (SCSL)

Extraordinary Chambers in the Courts of Cambodia (ECCC) Special Tribunal for Lebanon (STL).

Other courts also form part of the landscape of internationalized judicial bodies, but the five identified above are the most pertinent for our exploration of how the ICC should interact with national and regional authorities. The ICTY and ICTR are the closest analogies as they are both international courts without a tie to a specific domestic system, and each was located outside of the national jurisdiction at issue. Although the SCSL is different from the ICC in that it was a hybrid court comprising both international and national judges, and was located in the situation country, there are still strong similarities to the ICC in applying a statute and international law. All three courts, the ICTY, ICTR, and SCSL, needed to interact with national governments. The ECCC and STL are able to apply domestic law and are considered part of the judicial systems of Cambodia and Lebanon, respectively. While the domestic nature of the ECCC and STL is an important difference, the international

INT'L L. 510, 518-22 (2003) (discussing actual and perceived legitimacy). For an in-depth discussion of the meanings of legitimacy, see Peter Fabienne, Political Legitimacy, in The STANFord EnCyClopedia of Philosophy (Winter 2014), Edward N. Zalta (ed.), available at http://plato.stanford.edu/archives/win2014/ entries/legitimacy/. 
community is heavily involved in both of these courts. The judges are both international and national, the funding is largely international, and the relationship between the international community and the national authorities is important. The ICC can and indeed has already drawn on the experiences and jurisprudence of these two additional hybrid courts in the necessary interactions with states.

In order to understand how the ICC can benefit from the experiences of the earlier courts, it is helpful to recognize the similarities and differences between those courts and the ICC. Some of the most important characteristics to take into account are: 1) the relationship with the UN; 2) whether the court is temporary or permanent; 3) the governing body and accountability structure; 4) the location of the court; 5) limitations on jurisdiction; and 6) whether the foundation, in terms of the relationship with national systems, is primacy or complementarity. Each factor will be discussed briefly below and will play a part in the discussions of issues in the relationship between the international courts and national jurisdictions or regional bodies in the chapters of this book.

\section{A. RELATIONSHIP WITH THE UNITED NATIONS}

There are three creation mechanisms among the international and internationalized courts that largely define the relationship of the court with the UN. The ICTY and ICTR were established by the Security Council under the peace and security authority of Chapter VII of the Charter of the United Nations. ${ }^{2}$ Chapter VII does not explicitly reference courts at all. However, the Security Council viewed the courts as means of achieving peace and security in the regions at issue. The SCSL, ECCC, and STL were initiated through an agreement between the UN and the national government in each case. ${ }^{3}$ There is still a strong UN role similar to the ICTY and ICTR, but the courts are not exclusively creations of the $\mathrm{UN}$. There is a more direct role for the national governments in the

2 S.C. Res. 827, U.N. Doc. S/RES/827 (May 25, 1993); Statute of the International Criminal Tribunal for Rwanda, S.C. Res. 955, U.N. Doc. S/RES/ 955 (Nov. 8, 1994).

3 Agreement Between the United Nations and Sierra Leone on the Establishment of the Special Court for Sierra Leone, S.C. Res. 1313, U.N. Doc. S/RES/1313 (Aug. 4, 2000); Agreement Between The United Nations And The Royal Government Of Cambodia Concerning The Prosecution Under Cambodian Law Of Crimes Committed During The Period Of Democratic Kampuchea, G.A. Res. 57/228B, U.N. Doc. A/RES/57/228B (May 13, 2003); Statute of the Special Tribunal for Lebanon, S.C. Res. 1757, U.N. Doc. S/RES/1757 (May 30, 2007). 
hybrid SCSL, ECCC, and STL. In contrast to these earlier courts, the ICC was not established by the UN, either through Chapter VII or by an agreement. Instead, the ICC was created by a treaty, the Rome Statute. ${ }^{4}$ As of February 2016, there are 124 States-Parties to the Rome Statute.

Even though the ICC is not a UN creation, a relationship with the UN is established in the treaty. ${ }^{5}$ There are provisions of the Rome Statute that specify two important roles for the Security Council. One of the three referral mechanisms under Article 13 for jurisdiction in the ICC is a resolution by the Security Council under Chapter VII of the UN Charter. ${ }^{6}$ Article 16 further confers authority to the Security Council to defer an investigation or prosecution for renewable 12-month periods. ${ }^{7}$ The Security Council thus remains a potentially important actor in ICC adjudications, even without playing a role in the creation of the Court. In fact, the Security Council has referred two situations, Sudan and Libya, to the Court under the Article 13 provisions.

With the designated UN referral and deferral roles, it is necessary for the ICC to consider its interaction with the Security Council. In addition, if and when the crime of aggression enters into force, the Security Council will also have a role in the trigger mechanism anticipated for the prosecution of that crime. Consequently, the experiences of the UN-created courts are relevant to the ICC's interface with the Security Council. The connection with the Security Council, in turn, means that the states comprising the Council, especially the five states with veto power, are an important part of the relationship between the international criminal courts, including the ICC, and national jurisdictions or regional entities.

4 Rome Statute of the International Criminal Court, U.N. Doc. A/Conf. 183/9 (1998) [hereinafter Rome Statute].

5 There is, however, an agreement between the Court and the UN further defining their relationship. See Negotiated Relationship Agreement between the International Criminal Court and the United Nations, https://www.icc-cpi.int/NR/ rdonlyres/916FC6A2-7846-4177-A5EA-5AA9B6D1E96C/0/ICCASP3Res1_ English.pdf.

6 Under art. 13, the ICC may exercise jurisdiction if a "Prosecutor has initiated an investigation in accordance with article 15," and if a State Party has referred a situation in accordance with art. 14. Rome Statute art. 13(a-c).

7 Rome Statute art. 16. 


\section{B. TEMPORARY OR PERMANENT COURT}

All of the courts, except the ICC, have a temporary existence. Each has a specific mission and then the court will close. The SCSL has already completed its work. ${ }^{8}$ As of 2016, the ICTY is close to finishing its cases and the ICTR has finalized its last case. Residual mechanisms have been established to handle remaining or new cases and issues arising with those serving their sentences. ${ }^{9}$ In contrast, the ICC is a permanent court. Its interaction with national jurisdictions will continue and evolve in the future. With the ICC's potential to receive cases from many parts of the world, an effective and collaborative relationship with states is crucial for the future of international criminal justice.

\section{GOVERNING BODY AND ACCOUNTABILITY STRUCTURE}

All of the earlier courts (ICTY, ICTR, SCSL, ECCC, and STL) have the UN as a form of governing body. The Security Council adopted the Statutes for the ICTY and ICTR, and entered into agreements for the Statutes of the ECCC, SCSL, and STL. ${ }^{10}$ The Presidents of the ICTY and ICTR deliver reports to the Security Council. ${ }^{11}$ The President of the SCSL submitted reports to the Secretary-General of the UN and to the

8 See The Special Court for Sierra Leone and the Residual Special Court for Sierra Leone, http://www.rscsl.org/ for information regarding the closure of the Special Court for Sierra Leone in 2013. After its closure, "The Residual Special Court for Sierra Leone was established by an agreement between the United Nations and the Government of Sierra Leone to oversee the continuing legal obligations of the Special Court for Sierra Leone." Ibid.

9 See The Mechanism for International Criminal Tribunals at http://www. icty.org/sid/10874. "The Mechanism for International Criminal Tribunals was established by the United Nations to carry out a number of essential functions of the ICTR and ICTY after the completion of their respective mandates." Ibid.

10 Supra note 2.

11 Security Council Report, http://www.securitycouncilreport.org/oversightof-international-criminal-tribunals/. See, e.g., President of the ICTY to the UN, Report dated Dec. 10, 2014 from the President of the ICTY addressed to the President of the Security Council, http://www.icty.org/x/file/Press/Statements \%20and\%20Speeches/President/141210_president_meron_un_sc_en.pdf; Press Release, ICTR President Addresses Security Council (Dec. 16, 2005), http:// www.unictr.org/en/news/ictr-president-addresses-un-security-council. 
Government of Sierra Leone. ${ }^{12}$ The President of the STL similarly reports to both the UN Secretary-General and to the Government of Lebanon. ${ }^{13}$ In each instance, the accountability structure involves the UN and also a specific government for the three hybrid courts.

The governing body for the ICC is the ASP. ${ }^{14}$ Each State Party, which is each country that has ratified or acceded to the Rome Statute creating the ICC, has a representative in the ASP. Although the Statute was established by treaty, the ASP is the body responsible for amendments to the Statute and also for adoption of the Rules of Procedure and Evidence (RPE). It is also the ASP that elects the judges, the Prosecutor, and the Registrar. The existence of the ASP creates a different dynamic from the earlier courts. The UN, being a separate legal entity from the ICC, plays a less important role (although see above for the description of the referral and deferral authority of the Security Council), and instead the collective States-Parties assume the dominant governing position.

In each case, with the UN, a national government, or the collection of States-Parties in the ICC, the judges, prosecutor, and defense must strive to maintain an independent, impartial stance vis-à-vis their governing body. This independence and impartiality is crucial to the legitimacy of the courts as institutions. Nevertheless, the interaction with the governing body can bring politics into the equation for instance, in selecting the leading members of the courts, in funding, and in setting certain priorities. For instance, the ICTY and ICTR have been required to develop completion strategies and report on the progress to the Security Council. ${ }^{15}$ With 124 individual state representatives in the ASP, the ICC also encounters an element of national and international politics.

12 Eleventh and Final Report, http://www.rscsl.org/Documents/AnRpt11.pdf.

13 Report from President of the STL to the UN Secretary-General and the Prime Minister of Lebanon, Fifth Annual Report 2013-2014, https://www.stltsl.org/en/documents/stl-documents/presidents-reports-and-memoranda/2984-fifthannual-report-2013-2014.

14 For a description of the role of the ASP see Assembly of State Parties at http://www.iccnow.org/?mod=asp.

15 See supra note 10. Periodically, the Prosecutor of the ICC reports to the Security Council on judicial activities regarding the situation in Darfur, Sudan. See Twentieth Report of the Prosecutor of the ICC to the UNSC pursuant to UNSCR 1593 (2005), http://www.icc-cpi.int/iccdocs/otp/20th-UNSC-Darfurreport-ENG.PDF. 


\section{LOCATION OF THE COURT}

The ICTY, ICTR, STL, and ICC are all located in The Hague, in the Netherlands. Each is at quite a distance from the states in which the conduct occurred and from which the accused and witnesses come. In contrast, the SCSL and the ECCC are located in-country in Sierra Leone and Cambodia, respectively. The location of the courts has significant ramifications. It is much more difficult for survivors of the conflicts in the Balkans, Rwanda, Lebanon, and the various countries with situations in the ICC to observe the proceedings in the courts first hand. In Sierra Leone and Cambodia, the affected population is much more likely to be able to attend proceedings. ${ }^{16}$ Many commentators agree that the ability to see the proceedings leads to better understanding of the purpose of the courts and what is happening in the proceedings. ${ }^{17}$ The greater understanding, in turn, increases the legitimacy of the courts. ${ }^{18}$ As a way in which to ameliorate some of the distance, the ICTY, ICTR, STL, and ICC have outreach programs in the states involved in the cases. ${ }^{19}$

\section{E. LIMITATIONS ON JURISDICTION}

All of the courts, both earlier ones and the ICC, have some limitations on their jurisdiction. The limitations can be subject matter, seriousness of the

16 See infra Chapter 2, note 15 for discussion of the number of Cambodians attending proceedings at the ECCC.

17 See, e.g., Laura A. Dickinson, The Promise of Hybrid Courts, 97 AM. J. INT'L L. 295, 303 (April 2003).

18 Seeta Scully, Judging the Successes and Failures of the Extraordinary Chambers of the Courts of Cambodia, 13 AsIAn-PACIFIC L. \& POL'Y J. 300, 343-344 (2011) (discussing the importance of prosecutions that can be seen and understood in a local language to the legitimacy of the proceedings); Mark S. Ellis, Sovereignty And Justice: BALANCING THE Principle of CoMPlementARITY BETWEEN INTERNATIONAL AND DOMESTIC WAR CRIMES TRIBUNALS 24 (2014) (describing view in Serbia that their war crimes court had greater legitimacy than the ICTY). See also Jane E. Stromseth, Pursuing Accountability for Atrocities After Conflict: What Impact on Building the Rule of Law? 38 GEO. J. INT'L L. 251, 268 (2007) (noting that the ICTR and ICTY are "geographically and psychologically distant from those most affected by the atrocities," which, along with limited outreach, undermined the legitimacy of those tribunals).

19 See ICTY at http://www.icty.org/en/outreach/home; STL at http://www.stltsl.org/en/about-the-stl/structure-of-the-stl/registry/outreach; and ICC at https:// www.icc-cpi.int/en_menus/icc/structure\%20of\%20the\%20court/outreach/Pages/ outreach.aspx. 
case or perpetrators, temporal, and geographic. The ICC has additional limitations in its referral system, preconditions to jurisdiction, and admissibility provisions. The admissibility aspect is discussed below in subsection $\mathrm{F}$ on primacy and complementarity provisions.

The subject matter jurisdiction of the ICTY, ICTR, SCSL, ECCC, and ICC includes war crimes, ${ }^{20}$ crimes against humanity, and genocide. The ICTY and ICTR are limited to these three categories of crimes. At this point in time, the ICC is also limited to the same three types of crimes, although the ICC's jurisdiction may eventually include the crime of aggression. ${ }^{21}$ The SCSL's jurisdiction further included certain other serious violations of international humanitarian law committed in the context of a non-international armed conflict and some domestic crimes (which in practice were never used). ${ }^{22}$ The ECCC also includes the

20 War crimes encompass a number of different offenses, in part differentiated by whether there is an international conflict or a conflict not of an international character. For the ICTY, ECCC, and ICC, war crimes include grave breaches of the Geneva Conventions and violations of the laws and customs of war. Statute of the International Criminal Tribunal for the Former Yugoslavia, S.C. Res. 827, U.N. Doc. S/RES/827 (1993) art. 2, available at http://www. icty.org/x/file/Legal\%20Library/Statute/statute_sept09_en.pdf; Law on the Establishment of the Extraordinary Chambers, with inclusions of amendments as promulgated on Oct. 27, 2004 (NS/RKM/1004/006), http://www.eccc.gov.kh/ sites/default/files/legal-documents/KR_Law_as_amended_27_Oct_2004_Eng.pdf; Rome Statute art. 2(a). The ICTR's jurisdiction is Common Article 3 of the Geneva Conventions and Protocol II. Statute of the International Criminal Tribunal for Rwanda, art. 4, http://www.icls.de/dokumente/ictr_statute.pdf. The jurisdiction of the SCSL is also Common Article 3 of the Geneva Conventions and Protocol II. Statute of the Special Court for Sierra Leone, art. 3, http://www. rscsl.org/Documents/scsl-statute.pdf.

21 Rome Statute art. 5(d) ("an act of aggression is defined as the use of armed force by one State against another State without the justification of self-defense or authorization by the Security Council"). The ICC will not be able to exercise jurisdiction over the crime of aggression until after January 1, 2017. The Crime of Aggression, CICC, http://www.iccnow.org/?mod=aggression. In order for the ICC to exercise jurisdiction over the crime of aggression, at least 30 States-Parties have to ratify or accept the amendments and a decision is taken by two-thirds of the State Parties to activate jurisdiction. Ibid.

22 For example, the Statute for the Special Court for Sierra Leone recognizes child conscription as a violation of international humanitarian law and abusing girls under the age of 13 and 14 under Sierra Leonean law. Statute of the Special Court for Sierra Leone, arts. 4 and 5, http://www.rscsl.org/Documents/scslstatute.pdf. 
possibility of prosecuting for certain domestic crimes. ${ }^{23}$ The STL is unique among the courts included here in that its jurisdiction is exclusively over the crime of terrorism and related crimes. ${ }^{24}$ What all the courts have in common is that their jurisdiction is limited to severe crimes that cause international concern and often have political reverberations, both domestically and internationally.

The jurisdiction of the courts examined here is further limited to the most serious cases. For instance, the Statute of the ICTY authorizes prosecutions of "persons responsible for serious violations of international humanitarian law." 25 The SCSL authorizes prosecutions of "persons who bear the greatest responsibility for serious violations of international humanitarian law and Sierra Leonean law."26 The ICC Statute similarly limits prosecutions to "the most serious crimes of concern to the international community as a whole" 27 and further provides in its admissibility provision that a case must be of sufficient "gravity." 28 Not only have the courts restricted the prosecutions to the

23 The domestic crimes include: homicide, torture, and religious persecution. Law on the Establishment of the Extraordinary Chambers, with inclusions of amendments as promulgated on Oct. 27, 2004 (NS/RKM/1004/006), http:// www.eccc.gov.kh/sites/default/files/legal-documents/KR_Law_as_amended_27_ Oct_2004_Eng.pdf.

${ }^{24}$ Statute of the Special Tribunal for Lebanon, S.C. Res. 1757, art. 2, U.N. Doc. S/RES/1757 (2007) ("terrorism, crimes and offences against life and personal integrity, illicit associations and failure to report crimes and offences"), http://www.stl-tsl.org/en/documents/statute-of-the-tribunal/statute-of-the-specialtribunal-for-lebanon. In the first indictment, the charges included conspiracy aimed at committing a terrorist act; committing a terrorist act by means of an explosive device; two counts of intentional homicide with premeditation by using explosive materials; and one count of attempted intentional homicide with premeditation by using explosive materials. All accused were charged with the conspiracy count; for the other counts, the accused's participation was either charged as stated above or as accomplices to the same acts. Prosecutor v. Badreddine, Case No. STL-11-01/I/PTJ, Indictment, http://www.stl-tsl.org/en/ the-cases/stl-11-01/main/filings/indictments/f0007.

25 Statute of the International Criminal Tribunal for the Former Yugoslavia, available at http://www.icty.org/x/file/Legal\%20Library/Statute/statute_sept09_ en.pdf.

26 Statute of the Special Court for Sierra Leone, art. 1(1), http://www.rscsl. org/Documents/scsl-statute.pdf.

27 Rome Statute art. 5.

28 Rome Statute art. 17. See Margaret M. deGuzman, supra note 1 at 1460 (arguing that gravity threshold functions to allow cases in the middle of the spectrum; in so doing the Prosecutor often prioritizes the legitimacy perspectives 
most serious violations, but as time went on, all courts restricted prosecutions to those at high levels in political and military positions, who are viewed as bearing the greatest responsibility. ${ }^{29}$

All of the courts also have temporal limitations, although those differ with each court. Some of the courts have a temporal limitation only for the starting date of the jurisdiction. For instance, the ICTY has jurisdiction over crimes committed since 1991, with no end date to the jurisdictional time period. ${ }^{30}$ The ICC's jurisdiction also has a front-end limitation only, either from the entry into force of the Statute (July 1, 2002) or for those states ratifying or acceding to the treaty after July 1 , 2002, from the date of entry into force for that state unless the state signs a declaration accepting jurisdiction for earlier crimes. ${ }^{31}$ The SCSL's jurisdiction covered crimes committed after November 30, 1996. ${ }^{32}$ Other courts have temporal limitations on both the beginning and end dates. For example, the jurisdiction of the ICTR was limited to violations occurring

of some over others); Susana SáCouta and Katherine A. Cleary, The Gravity Threshold of the International Criminal Court, 23 AM. J. INT'L L. 800, 850 (arguing that the dual-use of gravity makes it difficult to determine when the Prosecutor is discussing gravity as a function of admissibility as in the LRA or as a discretionary tool as in the case of the situation in Iraq).

29 Although the ICTY originally prosecuted some lower-level individuals, such as Miroslav Tadić and Dražen Erdemović, they subsequently indicted only higher level individuals. See Press Release, Statement by Carla Del Ponte Prosecutor of the International Criminal Tribunal for the Former Yugoslavia on the investigation and prosecution of crimes committed in Kosovo (Sept. 29, 1999), http://www.icty.org/sid/7733 (stating that the primary focus of the Office of the Prosecutor (OTP) is the prosecution of the five senior most leaders). See Charles Chernor Jalloh, Prosecuting Those Bearing "Greatest Responsibility": The Contributions of the Special Court for Sierra Leone, in THE SIERRA LEONE COURT AND ITS LEGACY: THE IMPACT FOR AFRICA AND INTERNATIONAL CRIMINAL LAW (Charles Chernor Jalloh, ed., 2014), 589-623 (discussing the adoption of a "greatest responsibility" requirement either in practice or in statutes of the tribunals).

30 Statute of the International Criminal Tribunal for the Former Yugoslavia, art. 1, http://www.icty.org/x/file/Legal\%20Library/Statute/statute_sept09_en.pdf.

31 Rome Statute art. 11 provides that "1). The Court has jurisdiction only with respect to crimes committed after the entry into force of this Statute; 2) If a State becomes a Party to this Statute after its entry into force, the Court may exercise its jurisdiction only with respect to crimes committed after the entry into force of this Statute for that State, unless that State has made a declaration under article 12, paragraph 3."

32 See http://rscsl.org/ (note that the jurisdiction was limited, given that the conflict began in March 1991). 
between January 1, 1994 and December 31, 1994. ${ }^{33}$ The ECCC similarly has both a beginning and end date for its jurisdiction (April 17, 1975 to January 6, 1979). ${ }^{34}$ The STL has a beginning and end date, with the possibility of jurisdiction over later crimes. ${ }^{35}$

Although the ICC shares certain subject matter and temporal limitations with the earlier courts, the jurisdiction of the ICC is not nearly as restrictive geographically as is the case with the earlier courts. Because the earlier courts were established in response to or during specific conflicts, their territorial jurisdiction is circumscribed by the conflict. For example, the jurisdiction of the ICTY is the territory of the former Yugoslavia ${ }^{36}$ and the jurisdiction of the SCSL was the territory of Sierra Leone. ${ }^{37}$ The ICTR's jurisdiction was within Rwanda and neighboring states, with the added restriction for the latter that the accused had to be a Rwandan national. ${ }^{38}$ The STL and ECCC are similarly limited to the territory of their respective states. ${ }^{39}$

33 Statute of the International Criminal Tribunal for Rwanda, art. 1, http:// www.icls.de/dokumente/ictr_statute.pdf.

34 Law on the Establishment of the Extraordinary Chambers, with inclusions of amendments as promulgated on Oct. 27, 2004 (NS/RKM/1004/006), art. 1, http://www.eccc.gov.kh/sites/default/files/legal-documents/KR_Law_as_amended_ 27_Oct_2004_Eng.pdf.

35 "The Special Tribunal shall have jurisdiction over persons responsible for the attack of 14 February 2005 resulting in the death of former Lebanese Prime Minister Rafiq Hariri and in the death or injury of other persons. If the Tribunal finds that other attacks that occurred in Lebanon between 1 October 2004 and 12 December 2005, or any later date decided by the Parties and with the consent of the Security Council, are connected in accordance with the principles of criminal justice and are of a nature and gravity similar to the attack of 14 February 2005, it shall also have jurisdiction over persons responsible for such attacks." Statute of the Special Tribunal for Lebanon, S.C. Res. 1757, art. 2, U.N. Doc. S/RES/1757 (2007).

36 Statute of the International Criminal Tribunal for the Former Yugoslavia, art. 1, http://www.icty.org/x/file/Legal\%20Library/Statute/statute_sept09_en.pdf.

37 Statute of the Special Court for Sierra Leone, art. 1, http://www.rscsl.org/ Documents/scsl-statute.pdf.

38 Statute of the International Criminal Tribunal for Rwanda, art. 1, http:// www.icls.de/dokumente/ictr_statute.pdf.

39 "There is no explicitly territorial jurisdiction for the ECCC ... [but, since] the ECCC is a national court of Cambodia, [its] reach is confined by the territorial boundaries of the nation." David Scheffer, The Extraordinary Chambers in the Courts of Cambodia, in INTERNATIONAL CRIMINAL LAW (3rd edn. Cherif Bassiouni, ed. 2008). Statute of the Special Tribunal for Lebanon, S.C. Res. 1757, art. 1, U.N. Doc. S/RES/1757 (2007). 
In contrast, the ICC as a permanent court has very few limitations on its territorial jurisdiction, and further has jurisdiction based on nationality and Security Council referrals. As a result, the ICC's jurisdiction can sweep quite broadly and include both States-Parties and non-StatesParties. For States-Parties, the Court has jurisdiction if alleged violations occur on the territory of the State Party or anywhere in the world if allegedly committed by a national of a State Party. ${ }^{40}$ This means that the ICC could have jurisdiction for acts in a non-State Party. For instance, if a national of State Party Canada commits an offense in non-State Party India, jurisdiction would exist in the ICC. This basic jurisdiction is also extended to the territory of a non-State Party if that state accepts the jurisdiction of the ICC. This occurred with Côte d'Ivoire, which was not a State Party at the time it accepted jurisdiction of the ICC. Moreover, non-State Party acceptance would also extend to other locations in the world if the alleged crimes were committed by nationals of that state. In addition, if the Security Council refers a situation in a non-State Party to the ICC, the jurisdiction could be anywhere in the world. ${ }^{41}$ Current situations before the ICC that are based in the territory of a State Party include Uganda, the Democratic Republic of the Congo, the Central African Republic, Kenya, Mali, Georgia, and Côte d'Ivoire. As mentioned above, the situation in Côte d'Ivoire was originally based on the State's acceptance of jurisdiction, but Côte d'Ivoire is now a State Party. Two situations in non-States-Parties, Sudan and Libya, were referred by the Security Council. The potential, therefore, is for very broad jurisdiction in the ICC. The limitations for States-Parties largely rest with referral $^{42}$ and admissibility issues. ${ }^{43}$ There are more limits on jurisdiction for non-States-Parties. However, acceptance of jurisdiction by a non-State Party, referral by the Security Council, or alleged violations committed by a national of a State Party will provide the ICC with jurisdiction even when involving non-States-Parties.

\footnotetext{
40 Rome Statute art. 12.

41 Rome Statute art. 16.

42 Rome Statute art. 13 (the court may exercise jurisdiction if a situation is referred to the Prosecutor by the Security Council in accordance with Chapter VII of the Charter of the United Nations).

43 Rome Statute art. 17.
} 


\section{F. PRIMACY OR COMPLEMENTARITY}

One of the most significant differences between the ICC and the earlier courts is the underlying structure of its relationship with national jurisdictions. All of the earlier courts are based on a principle of primacy. The international courts, such as the ICTY, ICTR, and the SCSL, can preempt national jurisdictions from prosecuting individuals within their jurisdiction. ${ }^{44}$ The STL similarly has primacy over the regular courts of Lebanon. ${ }^{45}$ The ECCC, as a special chamber within the courts of Cambodia, also has de facto priority in its cases. ${ }^{46}$ However, only in a few cases did these tribunals need to exercise that power, and after the implementation of completion strategies, the ICTY and ICTR even transferred case files and cases to the relevant national jurisdictions.

In contrast, the ICC is built on a foundation of complementarity. National jurisdictions may preempt ICC jurisdiction if they exercise their option to genuinely investigate and prosecute. ${ }^{47}$ The prioritization of national adjudications necessarily impacts the relationship between states and the ICC in at least three ways:

1. The ICC will need to yield to bona fide, competent national adjudications.

2. There will be considerably more interaction and communication between the ICC and states when both have an interest in a case.

3. There will be a concomitantly greater need for coordination and cooperation.

44 Statute of the International Criminal Tribunal for the Former Yugoslavia, art. 9(2), http://www.icty.org/x/file/Legal\%20Library/Statute/statute_sept09_en. pdf; Statute of the International Criminal Tribunal for Rwanda, art. 8(2), http://www.icls.de/dokumente/ictr_statute.pdf; Statute of the Special Court for Sierra Leone, art. 7(2), http://www.rscsl.org/Documents/scsl-statute.pdf.

45 Statute of the Special Tribunal for Lebanon, S.C. Res. 1757, art. 4, U.N. Doc. S/RES/1757 (2007).

46 This language was used in an amicus curiae brief to question the ECCC's jurisdiction. See In The Extraordinary Chambers in the Courts of Cambodia (ECCC), Judicial Investigation Opened Against Kaing Guek Eav (alias 'Duch') Appeal of the Defense to the Pre-Trial Chamber (PTC) No. 002/14-08-2006, Brief of Stan Starygin, Amicus Curiae in Support of the Detainee, 8, available at http://www.haguejusticeportal.net/Docs/ECCC/Duch_Amicus_Curiae_Stan_ Starygin.pdf; See also art. 33, https://www.uni-marburg.de/icwc/dateien/law establishmentkrt.pdf (in accordance with existing procedure).

47 Rome Statute art. 17. 
With this body of information and experience from international criminal courts as a foundation, we will address five major areas and make recommendations for the ICC.

In Chapter 2 we examine the role of international criminal courts in fostering national prosecutions. Our analysis assesses what international criminal courts, international organizations, and national jurisdictions have done to date, and how the ICC as a court and as an international organization can best facilitate efforts to build national capacity.

Chapter 3 focuses on cooperation between courts at the international and national level, including the role of the Security Council. The chapter also reviews the concept of immunity, which is relevant in the context of surrender and extradition. We suggest best practices for the ICC to follow to improve on the necessary assistance and support from states and the Security Council.

Chapter 4 examines the choice by states to use alternatives to judicial processes, such as truth commissions. We find the legal issues significantly lacking in clarity and the underlying sociological issues highly complex. We recommend the creation of an expert panel to study the issues, and to propose amendments to the Rome Statute to clarify the position and understanding of the status of alternative mechanisms.

Chapter 5 takes us into uncharted territory, examining whether regional organizations and their human rights courts, such as the African Union's proposed criminal chamber, could play a role in dispensing justice as part of a wider enforcement system of international criminal law in addition to prosecutions within national and international tribunals. We discuss the idea of complementarity and whether it could be used to forge a relationship between the ICC and the African regional court.

In Chapter 6, we assess the effectiveness of non-governmental organizations (NGOs) in utilizing amicus curiae briefs to influence and guide international and ad hoc courts on substantive legal issues.

Finally, in Chapter 7, we synthesize the lessons learned from the earlier courts and summarize the steps we have proposed for the ICC. We find that strengthening national jurisdictions in their capacity, understanding, and options will assist in forging a strong partnership between those states and the ICC. It is also important to have a solid relationship and increased coordination among the ICC, international bodies such as the Security Council, and regional organizations. Our findings lead us to the conclusion that the ability to have a vibrant international, regional, and national collaboration is essential for the future of an effective system of international criminal justice. 